\title{
First report of Microstroma juglandis causing downy leaf spot or white mould on Celtis australis from Himachal Pradesh, India
}

Sunita Chandel* and Praneet Chauhan

Department of Plant Pathology, Dr. Y. S. Parmar University of Horticulture and Forestry, Nauni, Solan (H.P.) India Email: chauhanpraneet78@gmail.com

\section{ARITCLE INFO}

Received : 19.03 .2018

Revised : 10.09 .2018

Accepted : 23.09 .2018

\section{KEY WORDS :}

Celtis australis, Downy leaf spot,

Microstroma sp.

*Corresponding author:

schandelmpp@ rediffmail.com

\begin{abstract}
Microstroma sp. collected on living leaves of Celtis australis L. (Cannabaceae) from Himachal Pradesh, India is a new host record. Symptoms of the disease on leaves appeared in the form of small, circular to irregular, white coloured spots or mouldy growth surrounded by a yellow zone. The fungus isolated was identified as Microstroma juglandis on the basis of cultural appearance and morphological characters. The pathogen was able to induce the characteristic symptoms of downy leaf spot or white mould within 14-16 days after inoculation.
\end{abstract}

How to view point the article : Chandel, Sunita and Chauhan, Praneet (2018). First report of Microstroma juglandis causing downy leaf spot or white mould on Celtis australis from Himachal Pradesh, India. Internat. J. Plant Protec., 11(2) : 161-163, DOI : 10.15740/HAS/IJPP/11.2/161163, Copyright@ 2018: Hind Agri-Horticultural Society. 